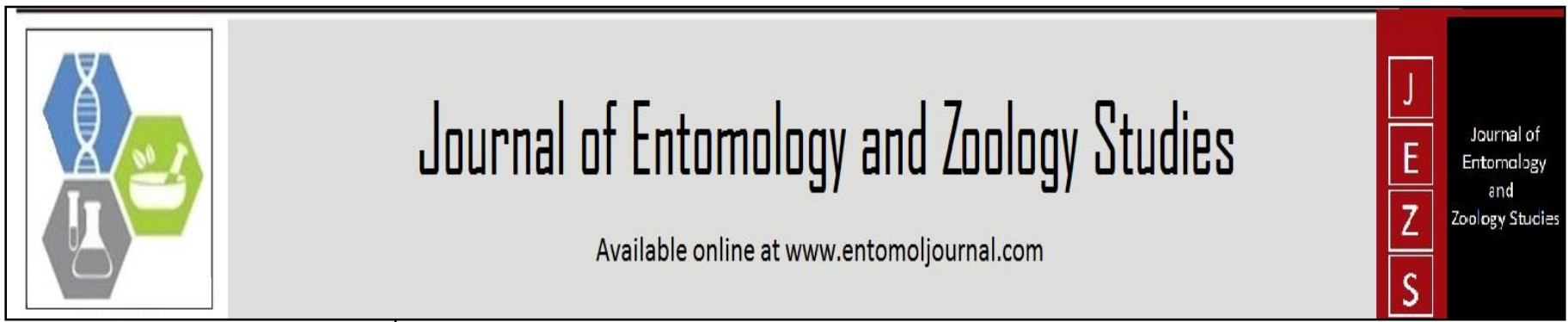

E-ISSN: 2320-7078

P-ISSN: 2349-6800

www.entomoljournal.com

JEZS 2021; 9(2): 1163-1167

(C) $2021 \mathrm{JEZS}$

Received: 04-01-2021

Accepted: 06-02-2021

Ayekpam Lanngamba Meitei Department of Forest Biology,

Tree Improvement and Wildlife

Sciences, College of Forestry,

Sam Higginbottom University of Agriculture Technology and

Sciences, Prayagraj,

Uttar Pradesh, India

\section{Somnath Sen}

Department of Forest Biology,

Tree Improvement and Wildlife

Sciences, College of Forestry,

Sam Higginbottom University of

Agriculture Technology and

Sciences, Prayagraj,

Uttar Pradesh, India

Tokpam Rohit Meetei

Department of Forest Biology,

Tree Improvement and Wildlife

Sciences, College of Forestry,

Sam Higginbottom University of

Agriculture Technology and

Sciences, Prayagraj,

Uttar Pradesh, India
Corresponding Author:

Ayekpam Lanngamba Meitei Department of Forest Biology,

Tree Improvement and Wildlife

Sciences, College of Forestry,

Sam Higginbottom University of

Agriculture Technology and

Sciences, Prayagraj,

Uttar Pradesh, India

\section{Studies on feeding behavior of Sangai deer (Rucervus eldii eldii) in Keibul Lamjao national park, Manipur (India)}

\section{Ayekpam Lanngamba Meitei, Somnath Sen and Tokpam Rohit Meetei}

DOI: $\underline{\text { https://doi.org/10.22271/j.ento.2021.v9.i2n.8591 }}$

\section{Abstract}

The Sangai deer (Rucervus eldii eldii) is an endangered species which is found only in KeibulLamjao National Park, Manipur (India) with an area of $40 \mathrm{~km}^{2}$. Selection of observation point and direct observation method were utilized to record certain behavioral pattern shown by the Sangai deer. Determination of food resources were carried out to identified feed species during the observation hour. The finding of the present study shows that the behavioral activities were notice more in the morning (dawn) than evening (dusk). The most favorable food by Sangai deer were Zizania latifolia (Kambong), Pragmitis karka (Tou), Saccharum munja (Khoimom), Carex cruciata (Humdang), Learsia hexandra (Hup), Alpinanigra (Pullei) and Hydechiumcoronarium (Loklei). Amongst the favorable food species, the most preferable food by the Sangai deer is Zizania latifolia while some of the individuals were seen consuming ashes (Tanggoi) during the observation. Intrusion of domestic animals within the park area may lead to severe calamities which then lead to the spread of many harmful diseases to Sangai deer and its inhabitants. Shyness of animal and sensitive behaviors of Sangai deer was observed. Questionnaire surveys were carried out among 40 respondents. The result suggested that the status of feeding must be taken care so that there should not be any alteration or changes in their behavior due to intrusion, local vegetables collector and disturbances.

Keywords: Sangai deer, Keibul Lamjao national park, feeding behavior, etc.

\section{Introduction}

The name of the National Park itself hold a distinct meaning as kei - Tiger, Bul - being captive or tied up or held together, Lamjao - vast land. The total area of the national park is 40 $\mathrm{km}^{2}$ which is covered by floating meadows of $26 \mathrm{~km}^{2}$ and the remaining $14 \mathrm{~km}^{2}$ consist of open water, hills or island (Tuboi et al., 2014) ${ }^{[9]}$. The place is as unique as it is the only floating national park found in the country and globally (Shamungou, 2010) ${ }^{[4]}$. The national park is located in the southern part of loktak Lake which is the largest fresh water lake in north eastern region of India (Lakshmi and Khundrakpam, 2009) ${ }^{[5]}$. The national park is over the floating biomass locally called phumdii. Phumdii is a marshy floating biomass consisting of soil and organic matter in various stages of decomposition (Singh, 1975) ${ }^{[8]}$. It is the only largest floating meadows in the world. Phumdii is the most unique and important part of the National park. The Keibul Lamjao National Park is the only natural habitat of the endemic and endangered Sangai deer which is the state animal of Manipur. Rucervus eldii eldii or the Sangai is a beautiful medium sized deer belonging to family cervidae, with uniquely distinctive antlers with extremely long brow tine, which form the main beam. The forward protruding beam appears to come out from the eyebrow which signifies its name, browantlered deer. The sexes are moderately dimorphic in body size and weight, tail is short and rump patch is not pronounced, dark reddish brown winter coat, which turns paler in summer. The females fawn all year round. The deer walks on the hind surface of its pasterns with mincing hops over floating foliage, and is hence also called the Dancing Deer (Singh and Khare, 2018) ${ }^{[6]}$. There are some special food plants preferred by the Sangai deer in the vegetation of phumdii and some of them are Zizania latifolia, Saccharum munja, Saccharum bengalensis, Erianthus procerus, Erianthus ravennae etc. They usually start grazing in early morning during dawn and continue till 8 am and which may extend to 10am. During the evening time they start from $3 \mathrm{pm}$ till $5 \mathrm{pm}$. The feeding behavior pattern of the Sangai deer can be seen in a freshly cut fire-line area where new shoots of grass started to grow. After feeding, they usually take rest under tall and thick reeds which turn to nocturnal behavior (Singsit, 2003). 
Among the favorable and preferable food for Sangai deer, some species that are usually use by local resident which act as an income generating plant. Some of them are sell in market and also used as material for thatching which then sell in market. Such interference and intrusion created by the human disturbed especially during the time of breeding. The local resident are unaware and collect plants only for their need but did not realize that the animal totally depend on such plants for their survival. The endemic species Rucervus eldii eldii is being affected due to the scarcity of food within its own natural habitat (Devi et al., 2014) ${ }^{[2]}$. Till now no one has explore and fully attempt on the floristic composition, lifeform structure and diversity of Keibul Lamjao National Park (KLNP). It is important to have the knowledge of composition and quantitative characters of vegetation for managing the national park. The composition of floristic in wildlife habitat has a great bearing on plant and animal interaction (Gupta, 2016) ${ }^{[3]}$.

The threat occurring in such species is that the local communities depend on the park resources for their livelihood which create a tremendous pressure on the park. The preferred forage species by the Sangai deer are heavily extracted by the local communities. Some of the forage species are Leersia hexandra, Oryza rufipogon, Capillipedium spp., Persicaria perfoliata, Oenanthe javanica and Imperata cylindrical (Tuboi et al., 2018) ${ }^{[9]}$.

\section{Materials and Methodology \\ Geographical Description}

The Keibul Lamjao National Park (Kei - Tiger, Bul - vast,
Lamjao-Large Land) is a national park in the Bishnupur district of the state of Manipur in India, the only floating park in the world which is located in the southern part of Loktak Lake. The total area of the KNLP is $40 \mathrm{~km}^{2}$ and covered by floating meadows of $26 \mathrm{~km}^{2}$ and the remaining $14 \mathrm{~km}^{2}$ consist of open water, hills or island. The park is located between $29^{\circ}$ $27^{\prime} \mathrm{N}$ and $24^{\circ} 31^{\prime} \mathrm{N}$ latitudes and $93^{\circ} 53^{\prime} \mathrm{E}$ and $93^{\circ} 55^{\prime} \mathrm{E}$ longitudes. The unique of the national park is the floating meadows locally known as phumdii. The national park is divided into two parts: Range 1 and Range 2. Each range has several watch tower (Machan). Under the Range-1, the main watch tower are located in IB-1, IB-2, Thangbrelyangbi, Sagram and in Range-2 it is located in Khodrak, Nongmaikhong, Ithai, Chingthi and some small tower which is made from bamboo are within 2 to $3 \mathrm{~km}$ away from the main tower for each range respectively. Likewise, there are three more watch tower which are located at the top of the island and those island are Toya, Chingjao and Chinglukok. Both Chingjao and Chinglukokis believe to be as Twin Island locally known as Pabot. Several boats are available for travelling in the island. All the main tower, bamboo machan and places which are mention above are the places in which research work is carried out and utilize of those towers during the research work and field survey by the researcher and staff member of KeibulLamjao National Park and Manipur Forest Department. The Feeding behaviour of Sangai deer (Rucervus eldii eldii) in KeibulLamjao National Park were studied in Manipur (India) during research work from January to March 2020.

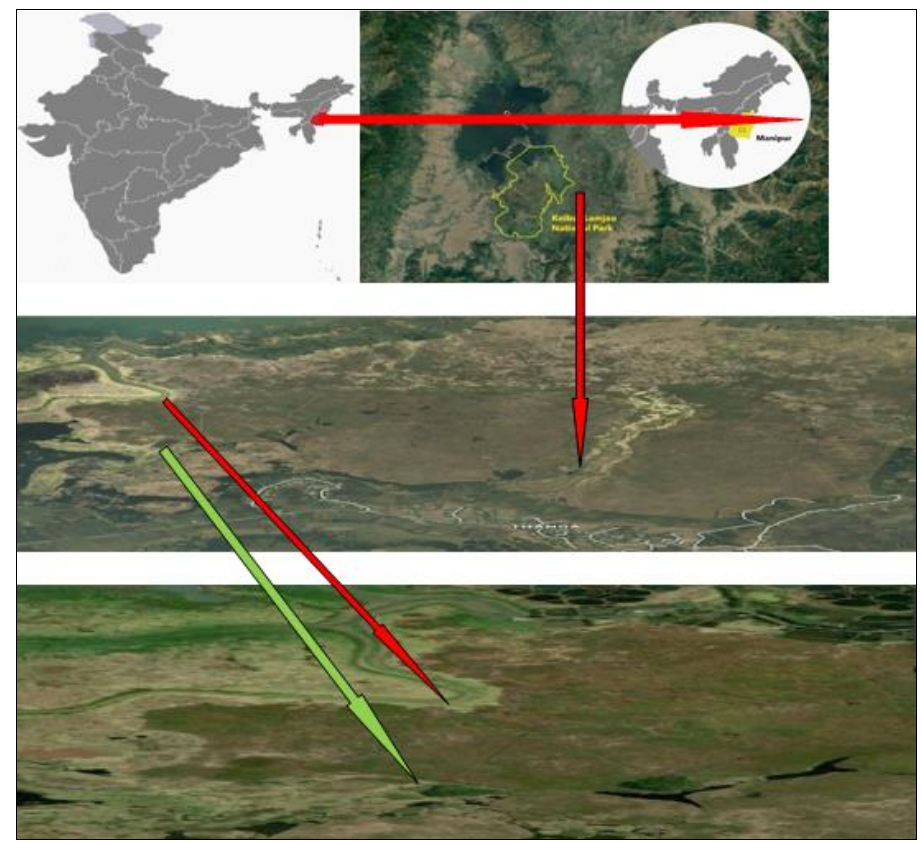

Fig 1: Geographical location of study area as per satellite imaging technique.

\section{Materials}

The materials like Phone, Camera, Bamboo stick, Binocular, Watch, Data collection sheet, Boat, Life jacket, Telescope, Boot, Telescopewere use for recording data by direct observation of the Sangai deer and to find out the preferable food species, feeding habits.

\section{Selection of Observation Point}

Most of the areas were covered by floating biomass (Phumdii) so it was very hard to observe and collect data. Since it is hard, therefore few observation points were selected where no obstacle reside and has clearer view than any other places (Ayas et al., 2012).

\section{Direct Observation}

The aim of choosing observation points were to take direct observation during the daily process of collecting behavioral data of the species. The data were recorded by direct observation method with the help of binocular and Cannon 60D digital DSLR Cameras with 70-300mm lens. 
Observations were conducted during dawn and dusk around 6 to 3 hours respectively. Longer and shorter amount of hours depend on daily climate as climate changes every day. The best time for observation was 4:30 am to 9:00 am and 2:00 pm to 5:00 pm during the study hour (Ayas et al., 2012) ${ }^{[1]}$.

\section{Determination of food habits}

Determination of food habit were done by direct observation method where feeding activity of Sangai deer occurred through binocular, canon 60D and followed by onsite inspection of food plants.

\section{Ad-libitum Sampling}

In this method, data and information are recorded as much as possible. As it is a non-systematic method the collected data and information are often used in field notes. During the observation the results presented may be unfairness due to the situation, attention given by an individual for attraction, behaviour. From this method, the collected data contains the
Feeding behaviour.

\section{Questionnaire}

Questionnaires were prepared to collect the data regarding the main objectives of the research work on 40 respondents. The questionnaires were conducted in neighboring village of the national park and some forest guard who were acted as guide during the research work. Questionnaires were conducted in off day of the national park as it is hard to conduct in regular days.

\section{Results and Discussion}

The Feeding behaviour of Sangai deer (Rucervus eldii eldii) in KeibulLamjao National Park were studied in Manipur (India) during research work from January to March 2020. The results obtained were the following:

\section{Feeding behaviour}

Table 1: Behaviour of Sangai deer during feeding and associated responses

\begin{tabular}{|c|c|c|c|c|}
\hline Gender & Social and Feeding structure & Competition & Time of day & Response to disturbances \\
\hline $\begin{array}{l}\text { Male } \\
(\text { Stag) }\end{array}$ & $\begin{array}{c}\text { Graze as a herd and sometime } \\
\text { separated or alone, such nature can be } \\
\text { clearly seen in dawn rather than dusk, } \\
\text { fond of Manchurian wild rice }\end{array}$ & $\begin{array}{l}\text { Male are often aggressive } \\
\text { during mating season, they } \\
\text { compete each other for } \\
\text { female, territory and } \\
\text { hierarchy, no competition } \\
\text { during grazing. }\end{array}$ & $\begin{array}{l}\text { They tend to graze as a herd such } \\
\text { nature can be seen dawn rather } \\
\text { than dusk. If the sun rises they } \\
\text { move to bushes to take rest or } \\
\text { turn to nocturnal behavior. }\end{array}$ & $\begin{array}{l}\text { Very sensible and aggressive } \\
\text { nature can be seen. If } \\
\text { disturbances and intrusion } \\
\text { continues, they turn to } \\
\text { nocturnal behavior easily. }\end{array}$ \\
\hline $\begin{array}{c}\text { Female } \\
\text { (Hind) }\end{array}$ & $\begin{array}{l}\text { Graze together as a herd and separate } \\
\text { when pregnant, can be seen during } \\
\text { dawn, daylight and disappear during } \\
\text { dusk as they seek for safer place, } \\
\text { usually fond of Manchurian wild rice }\end{array}$ & $\begin{array}{l}\text { No competition between } \\
\text { female but they are often led } \\
\text { by the dominant one, no } \\
\text { competition during grazing. }\end{array}$ & $\begin{array}{c}\text { Can be seen as a herd but } \\
\text { sometime only mother (Hind) and } \\
\text { fawn seen gazing. }\end{array}$ & $\begin{array}{l}\text { Sensible and aggressive can be } \\
\text { seen and also protective of } \\
\text { fawn towards intrusion. }\end{array}$ \\
\hline $\begin{array}{l}\text { Young } \\
\text { (Fawn) }\end{array}$ & $\begin{array}{l}\text { Graze together with mother for } \\
\text { almost } 5 \text { to } 6 \text { month and separate } \\
\text { afterwards }\end{array}$ & $\begin{array}{l}\text { Competition occurs when } \\
\text { they are one year old. }\end{array}$ & $\begin{array}{c}\text { Always stay with mother (Hind) } \\
\text { and follows where she goes and } \\
\text { play nearby her mother }\end{array}$ & $\begin{array}{l}\text { As the herd and mother is } \\
\text { sensible fawn also become } \\
\text { sensible following their step. }\end{array}$ \\
\hline
\end{tabular}

The data presented in the graphical presentation (Fig. 1) shows the Sangai deer consuming food in different days and placesduring January and February with more and lesser at the end of February till March. The amount of food available were less during January and February and has more chances of sighting Sangai deer as they travel and search for food for their daily need. During the end of February till March food were found abundantly as new leaves arises and as it grow taller the amount of Sangai deer sighted were less which inturn they travel less for food.

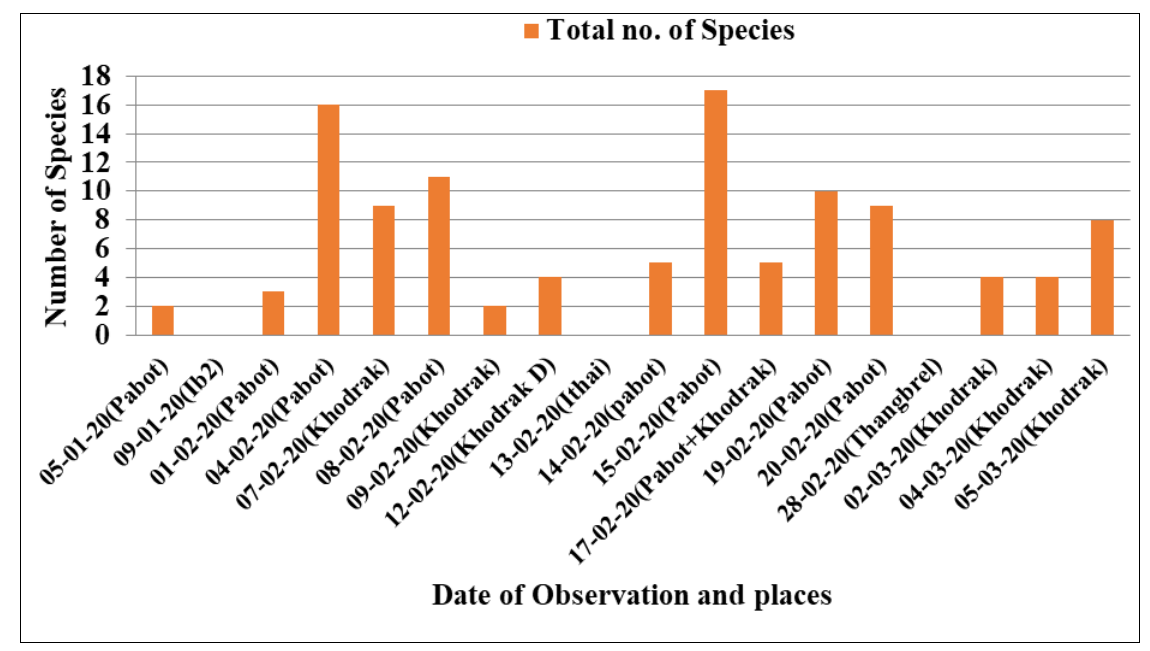

Fig 1: Graphical presentation of Sangai deer sighted consuming food in different days and places.

\section{Study site of Pabot (Chinglukok)}

The data presented in pie chart (Fig. 2) shows that the most preferable food species of Sangai deer in Pabot (Chinglukok) is Kambong having (45\%) and followed by $\operatorname{Hup}(21 \%)$, Tou
(14\%), Humdang (9\%) while the least preferred are Khoimom with (4\%), Loklei (3\%), Tanggoi (Ashes) (3\%), Pullei(1\%) respectively. 


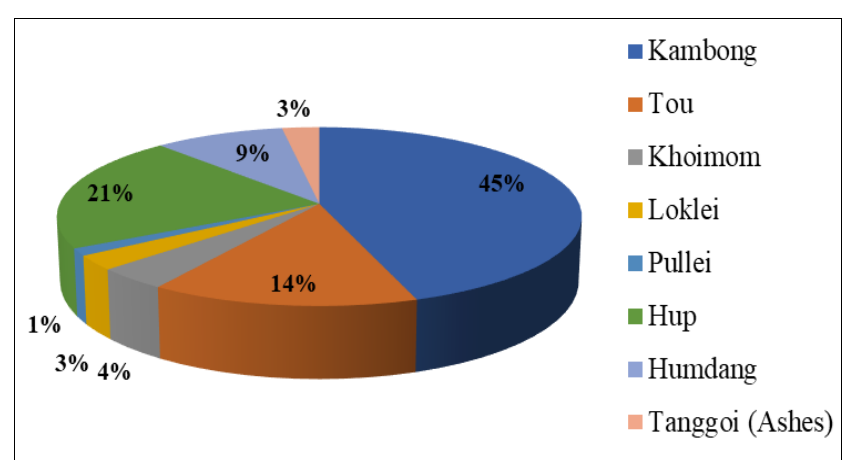

Fig 2: Pie-chart exhibiting preferable food species and flora of Sangai deer in Pabot (Chinglukok).

\section{Study site of Khodrak}

The data presented in pie chart (Fig. 3) shows that the most preferable food species of Sangai deer in Khodrak with highest percent having Kambong (52\%) and followed by Hup(15\%), Tanggoi (Ashes) (12\%) while the least preferred with Tou (6\%), Khoimom(6\%), Loklei (6\%), Humdang (3\%), Pullei (0\%) respectively.

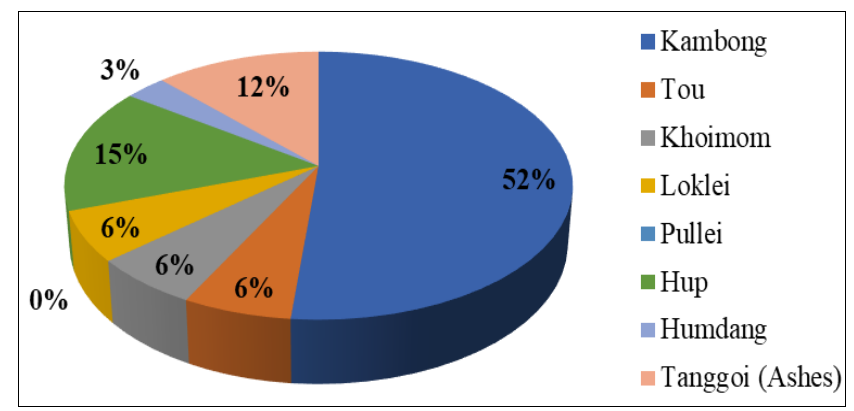

Fig 3: Pie chart exhibiting preferable food species of Sangai deer in Khodrak.

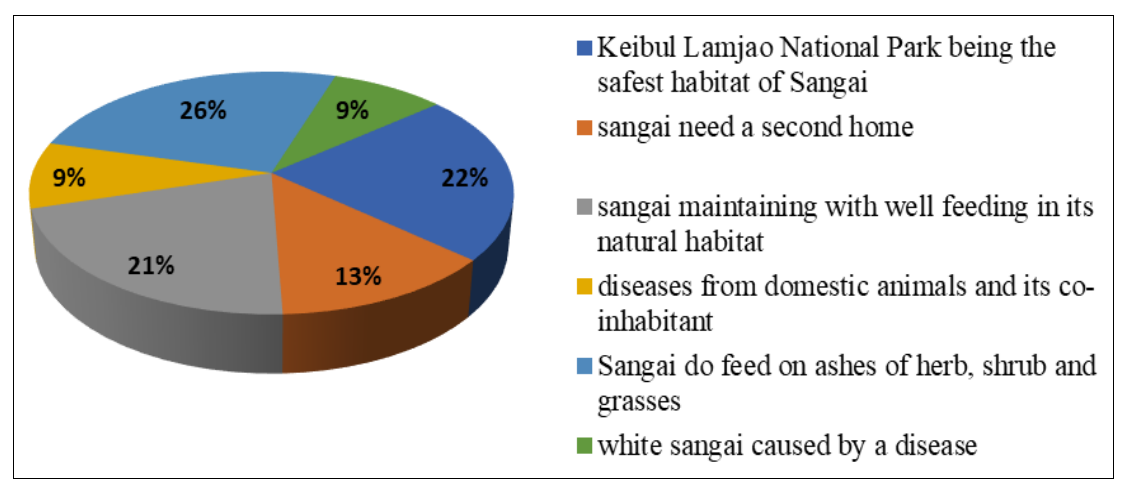

Fig 5: Pie chart showing percentage of respondent of the Questionnaire.

Table 2: List of common feed grass and description of commonly consumed by Sangai deer

\begin{tabular}{|c|c|c|c|c|c|}
\hline Sl.no & Scientific name & Common name & Local name & Family & Description \\
\hline 1. & Zizania latifolia & $\begin{array}{l}\text { Manchurian wild } \\
\text { rice }\end{array}$ & Isingkambong & Poaceae & $\begin{array}{c}\text { About } 3 \text { to } 4 \text { feet tall, young twig is edible, Use as fodder for both } \\
\text { domestic and wild animal. }\end{array}$ \\
\hline 2. & Pragmitis karka & Tall reed, Nal & Tou & Poaeceae & $\begin{array}{l}\text { About } 10 \text { to } 15 \text { feet tall, Use as fodder, firewood and construction of } \\
\text { houses like hut. }\end{array}$ \\
\hline 3. & Saccharum munja & Munja & Khoimom & Poaeceae & $\begin{array}{c}\text { About } 10 \text { to } 15 \text { feet tall, Use as fodder, firewood and construction of } \\
\text { houses like hut. }\end{array}$ \\
\hline 4. & Carex cruciata & Cross grass & Humdang & Cyperaceae & $\begin{array}{l}\text { Around } 2 \text { to } 3 \text { feet tall, Use as fodder for both domestic and wild } \\
\text { animals }\end{array}$ \\
\hline 5. & Learsia hexandra & Southern cutgrass & Hup & Poaceae & About 2 feet tall, Use as fodder for both domestic and wild animals \\
\hline 6. & Alpinanigra & $\begin{array}{c}\text { Thai ginger, } \\
\text { Galangal }\end{array}$ & Pullei & Zingiberaceae & $\begin{array}{l}\text { Local people use young shoot as vegetable for its aromatic taste, Size } \\
\text { of about } 3 \text { to } 4 \text { feet tall. }\end{array}$ \\
\hline 7. & $\begin{array}{l}\text { Hedychium } \\
\text { coronarium }\end{array}$ & White ginger lily & Loklei & Zingiberaceae & $\begin{array}{l}\text { Local people use young shoot as vegetable for its aromatic taste, Size } \\
\text { of about } 3 \text { to } 4 \text { feet tall. }\end{array}$ \\
\hline
\end{tabular}

The data presented in pie chart (Fig. 4) shows that the percentage of each grass species consumed by the Sangai deer during the observation in Keibul Lamjao National Park. Given the above figure, it has found out that kambong (Zizania latifolia) has the highest percentage of consumption of about (47\%) followed by (19\%) of Hup (Lersiahexandra), $(12 \%)$ of Tou (Pragmitis karka) while the least preferred with $(7 \%)$ by Humdang (Carex cruciata), (5\%) of Khoimom (Saccharum munja), (5\%) of Tanggoi (Ashes), (4\%) of Loklei (Hedychium coronarium) and (1\%) of Pullei (Alpinanigra).

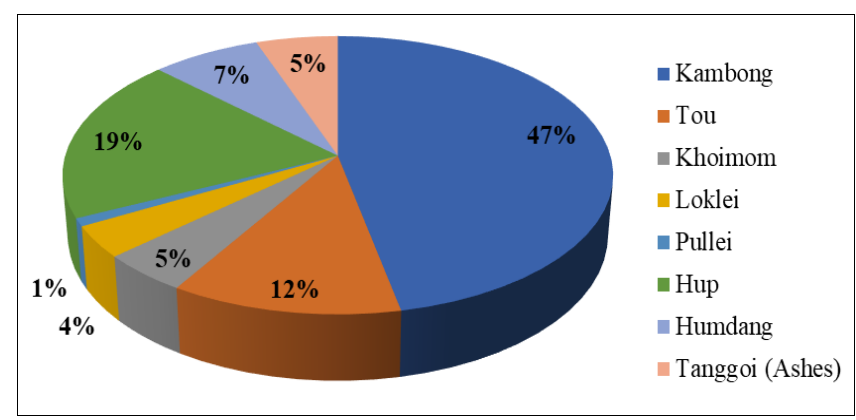

Fig 4: Pie chart showing percentage of grass species consumed by the Sangai deer.

\section{General information of feeding Behaviour}

The data presented in pie chart (Fig. 5) shows that the percentage of respondent of the questionnaire of KeibulLamjao National Park being the safest habitat of Sangai by (22\%), Sangai need a second home by (13\%), Sangai maintaining with well feeding in its natural habitat by (21\%), diseases from domestic animals and its co-inhabitant by (9\%), Sangai do feed on ashes of herb, shrub and grasses by $(26 \%)$, white Sangai caused by a disease by $(9 \%)$.

Keibul Lamjao National Park being the safest habitat of Sangai

sangai maintaining with well feeding in its

domimals and its co-

Sangai do feed on ashes of herb, shrub and

white sangai caused by a disease 


\section{Conclusion}

The study indicates that the main food preference of Sangai deer (Rucervus eldii eldii) is Zizania latifolia (Kambong) with more than $50 \%$ as compared to the remaining food resources or flora.Also intrusion of domestic animals within the park area may lead to severe calamities which then lead to the spread of many harmful diseases to Sangai deer and its inhabitants. The result suggested that the status of feeding and breeding must be taken care so that there should not be any alteration or changes in their behavior due to intrusion, local vegetables collector and disturbances.

\section{Acknowledgement}

The authors thank the authorities of Manipur Forest Department and Keibul Lamjao National Park for permitting to work in the park. We also acknowledge Oinam Rajen and Ningthoujam Kumarjit who gave us their support with all they had and helped me to their extent.

\section{References}

1. Ayas S, Muhibullah Jamilm, Anjum AA, Khan MA, Qamar MF. Behaviour and biology of Ovis orientalis (Urial) in Kotal Wild life Park and Borraka Wildlife Sanctuary in Kohat. The Journal of Animal \& Plant Sciences 2012;22(1):29-31.

2. Devi MH, Singh PK, Choudhury MD. Income generating plants of Keibul Lamjao National Park, Loktak Lake, Manipur and man-animal conflicts. Pleione 2014;8(1):3036.

3. Gupta A. Phytodiversity analysis of Keibul Lamjao National Park with a Note on productivity. CAS in life Sciences, Manipur University 2016.

4. Shamungou KH. Endangered Manipur Brow-antlered deer (An Environmental Assessment). The Department of Forest Sanjenthong, Imphal, Government of Manipur 2010.

5. Singh AL, Khundrakpam ML. Phumdi proliferation: A case study of loktak lake, Manipur. Water and Environmental Journal 2009, 99-105.

6. Singh M, Khare N. Distribution, status and conservation of Sangai deer (Rucervus eldii eldii) in Manipur, India. Journal of Entomology and Zoology Studies 2018.

7. Singsit S. Update on Manipur Brow-antlered deer or "Sangai" (Cervus eldii eldii) in KeibulLamjao National park in Manipur. Zoos' Print, 2003, 17(12).

8. Singh R. Keibul Lamjao Sanctuary and the Brow antlered deer- 1972 with notes on a visit in 1975. Journal of the Bombay Natural History Society, 1975, 72(2).

9. Tuboi C, Hussain SA. Factor affecting forage selection by the endangered Eld's deer and Hog deer in the floating meadows of Barak-Chindwin Basin of North-East India. Elsevier GmbH 2014.

10. Tubo C, Badola R, Hussain SA. Rapid assessment of proposed reintroduction sites for the Manipur's Brow antlered deer or Sangai. Indian Forester 2018;144(10):893-899. 